\title{
Cnidium officinale Makino extract induces apoptosis through activation of caspase-3 and p53 in human liver cancer HepG2 cells
}

\author{
HEEOK HONG ${ }^{1}$, JEONG CHEOL AN ${ }^{2}$, JOSEPH F. DE LA CRUZ ${ }^{2,3}$ and SEONG-GU HWANG ${ }^{2}$ \\ ${ }^{1}$ Department of Medical Science, Konkuk University School of Medicine, Seoul 05029; ${ }^{2}$ Division of Animal Life \\ and Environmental Science, Hankyong National University, Anseong-si, Gyeonggi-do 17579, Republic of Korea; \\ ${ }^{3}$ College of Veterinary Medicine, University of the Philippines Los Baños, Los Baños, Laguna 4031 Philippines
}

Received August 17, 2016; Accepted July 21, 2017

DOI: 10.3892/etm.2017.4916

\begin{abstract}
A number of diverse studies have reported the anticancer properties of Cnidium officinale Makino (CO). However, the apoptotic effect of this traditional medicinal herb in human hepatocellular carcinoma cells (HepG2) remains to be elucidated. Therefore, the present study investigated the ability of $\mathrm{CO}$ to reduce cell viability through apoptotic pathways. Cell viability was determined using the 2,3-bis [2-methyloxy-4-nitro-5-sulfophenyl]-2H-tetrazolium-5-carboxanilide assay. $\mathrm{CO}$ extract-induced apoptosis in HepG2 cells was assessed by Hoechst 33258 staining. The cell cycle was monitored using fluorescence-activated cell sorting analysis with propidium iodide staining. Furthermore, the present study explored whether various signaling molecules associated with HepG2 cell death were affected by $\mathrm{CO}$ treatment, including caspase-3, B-cell lymphoma 2 (Bcl-2), tumor protein p53 (p53), cyclin-dependent kinase 4 (CDK4) and cyclin D. The expression levels of these genes were examined by reverse-transcription polymerase chain reaction and western blotting. The expression levels of caspase- 3 and p53 were upregulated with $\mathrm{CO}$ extract treatment, whereas those of Bcl-2, CDK4 and cyclin D were significantly downregulated. Cleaved caspase-3 expression was upregulated following treatment with $\mathrm{CO}$ extract in a dose-dependent manner. Collectively, the data suggest that $\mathrm{CO}$ extract has the potential to induce apoptosis of HepG2 cells and may act by suppressing the cell cycle, which leads to caspase- 3 cleavage and p53 signaling.
\end{abstract}

Correspondence to: Professor Seong-Gu Hwang, Division of Animal Life and Environmental Science, Hankyong National University, 327 Chungang-ro, Anseong-si, Gyeonggi-do 17579, Republic of Korea

E-mail: sghwang@hknu.ac.kr

Key words: Cnidium officinale Makino, cell cycle, HepG2, apoptosis, tumor protein p53

\section{Introduction}

Hepatocellular carcinoma is a well-known malignant tumor whose incidence and mortality rate are increasing worldwide (1). Multiple genetic and epigenetic modifications play an important role in this cancer (2), and some viral infections have been reported to promote liver cancer progression by disrupting the normal cellular mechanisms of apoptosis (3).

Apoptosis is programmed cell death, and it has been shown to play an important role in preventing cancer by repairing damaged DNA in response to mutation $(4,5)$. Induction of apoptosis is a chemopreventive process that involves activation of the p53-dependent apoptotic cell death pathway (6-8). The tumor suppressor gene p53 is also a transcription factor that regulates cell cycle and DNA damage-induced cell mutation through the activation of caspase, a cysteine protease. Activation of anti-apoptotic proteins, such as B-cell lymphoma (Bcl-2), conversely, can delimit apoptosis reduction and deactivation of pro-apoptotic factors such as Bcl-2-associated X protein (Bax) (9).

Natural compounds have an abundance of polyphenols and can be used as chemoprevention agents against malignant cancers in humans (10). Cnidium officinale Makino (CO) has been used historically in traditional Eastern medicine to enhance stamina and manage pain. Owing to the pharmacological properties associated with the abundant polyphenol composition of $\mathrm{CO}$, it has been suggested as a potential herbal treatment for use in metabolic diseases and various forms of cancer (11-14).

However, the efficacy of $\mathrm{CO}$ in the treatment or prevention of cancer has not been fully established. In this study, we investigated the methanol extract of $\mathrm{CO}$ as a new alternative treatment against liver cancer. Our study demonstrates the potent inhibitory effects of the extract against proliferative liver cancer via downregulation of the cell cycle and induction of apoptosis. Our results suggest that $\mathrm{CO}$ may have therapeutic applications in diverse forms of liver diseases.

\section{Materials and methods}

Materials and reagents. The plant extraction was performed as previously described by Jung et al (15) with a few modifications. CO was obtained from the Dongguk University Oriental 
Hospital (Korea). The roots of $\mathrm{CO}(50 \mathrm{~g})$ were blended, and the crude powder was precipitated with $3,000 \mathrm{ml}$ of methanol (80\%) at $37^{\circ} \mathrm{C}$ for 3 days. The methanol extracts were concentrated using a rotary evaporator at $60^{\circ} \mathrm{C}$ under vacuum conditions. The extract was dissolved in $50 \mathrm{ml}$ of sterile deionized water. The aqueous solution was then lyophilized by freeze-drying at $-60^{\circ} \mathrm{C}$. The cell culture materials were purchased from Thermo Fisher Scientific (Boston, MA, USA). Antibodies and other laboratory reagents were purchased from Cell Signaling Technology Inc. (Beverly, MA, USA) and Sigma-Aldrich (St. Louis, MO, USA), respectively.

Cell culture. Human hepatoma cells (HepG2) were purchased at the Korean Cell Line Bank (Seoul, Korea). The Chang liver cells were obtained from Seoul National University (Seoul, Korea). HepG2 cells and the Chang liver cells were cultured in Dulbecco's modified Eagle's medium (DMEM) containing $10 \%$ fetal bovine serum (FBS) and 1\% penicillin-streptomycin. The cells were maintained under an atmosphere of $95 \%$ air $/ 5 \%$ $\mathrm{CO}_{2}$ at $37^{\circ} \mathrm{C}$. These cells were trypsinized and maintained every 1-2 days.

Determination of cell viability. The effects of different concentrations of CO $(100-1,000 \mu \mathrm{g} / \mathrm{ml})$ on viability of the Chang liver cells and HepG2 cells were investigated by the 2,3-bis [2-methyloxy-4-nitro-5-sulfophenyl]-2H-tetrazolium-5-carboxanilide (XTT) assay (EZ-Cytox cell viability assay kit; Daeil Lab Service, Seoul, Korea), respectively. Briefly, $5 \times 10^{4}$ cells were seeded in a 96 -well microplate and incubated in DMEM under $5 \% \mathrm{CO}_{2}$ at $37^{\circ} \mathrm{C}$ for $24 \mathrm{~h}$. Then the cells were treated with different concentrations of $\mathrm{CO}$ (dissolved in DMEM) for $24 \mathrm{~h}$. To measure cell viability, $10 \mu \mathrm{L}$ EZ-Cytox was added to each well and the absorbance was measured at $460 \mathrm{~nm}$ using a microplate spectrophotometer (Molecular Devices, Sunnyvale, CA, USA). The viability of CO-treated cells was expressed as a percentage of the control cell viability.

Apoptotic analysis with Hoechst 33258 staining. CO extract-induced apoptosis in HepG2 cells was assessed by Hoechst 33258 staining. The cells were seeded at a density of $5 \times 10^{4}$ cells/well in a 96-well culture plate and were incubated in DMEM at $37^{\circ} \mathrm{C}$ in $5 \% \mathrm{CO}_{2}$ for $12 \mathrm{~h}$. Then the cells were pretreated with $\mathrm{CO}$ extract $(0,100,250,500,750$ and $1,000 \mu \mathrm{g} / \mathrm{ml}$ ) and incubated again for $24 \mathrm{~h}$. Following treatment, the media were removed and stained with $1 \mu \mathrm{M}$ Hoechst 33258 staining at room temperature for $60 \mathrm{~min}$. After which, all the solutions were removed and then washed twice with $100 \mu 1$ PBS, and observed by the Cytation 3 Cell Imaging Multi-Mode reader (BioTek Instruments, Inc., Winooski, VT, USA).

Cell cycle analysis. Flow cytometry analysis was used to measure the proportion of HepG2 cells in the different stages of the cell cycle. HepG2 cells were seeded in 6-well plates at $1 \times 10^{6}$ cells $/ \mathrm{ml}$ and incubated for $24 \mathrm{~h}$. The cells were incubated with CO extract $(0-1,000 \mu \mathrm{g} / \mathrm{ml})$ for $24 \mathrm{~h}$, and were then harvested and washed twice with phosphate-buffered saline (PBS). Each sample was fixed in $1 \mathrm{ml}$ of $70 \%$ ethanol for $2 \mathrm{~h}$ at $-20^{\circ} \mathrm{C}$ and the samples were centrifuged. The collected cells were resuspended in PBS containing $50 \mu \mathrm{g} / \mathrm{ml}$ propidium iodide (PI) and $100 \mu \mathrm{g} / \mathrm{ml}$ RNAse A and incubated in the dark for $30 \mathrm{~min}$ at room temperature. Cell cycle was analyzed using the BD FACSCalibur flow cytometer (BD Biosciences, Franklin Lakes, NJ, USA). The data were analyzed using the BD CellQuest Pro software.

Reverse transcription-polymerase chain reaction (RT-PCR). Total RNA was isolated from HepG2 cells pre-treated with varying concentrations of the extract using TRI-reagent (MRC, Cincinnati, OH, USA) according to the manufacturer's instructions. Briefly, cDNA was synthesized using $0.5 \mu \mathrm{g}$ of total RNA and the Improm II reverse transcription system with oligo-deoxythymidine (oligo-dT) primers (Promega, Madison, WI, USA). The following semi-quantitative reverse transcription-polymerase chain reaction (RT-PCR) conditions were used for amplification; initial denaturation at $95^{\circ} \mathrm{C}$ for $10 \mathrm{~min}$ and 32 cycles of denaturation at $94^{\circ} \mathrm{C}$ for $1 \mathrm{~min}$, annealing at $60^{\circ} \mathrm{C}$ for $1 \mathrm{~min}$ and extension at $72^{\circ} \mathrm{C}$ for $1 \mathrm{~min}$. The following primers were used for RT-PCR; caspase-3, sense primer, 5'-TTT TTC AGA GGG GAT CGT TG-3', and antisense primer, 5'-CGG TTA ACC CGG GTA AGA AT-3'; Bcl-2, sense primer, 5'-CTG CGA AGA ACC TTG TGT GA-3', and antisense primer, 5'-TGT CCC TAC CAA CCA GAA GG-3'; p53, sense primer, 5'-GCT CTG ACT GTA CCA CCA TCC-3', and antisense primer, 5'-CTC TCG GAA CAT CTC GAA GCG-3'; CDK4, sense primer, 5'-ATG GCTGCCACTCGATATGAACCC-3', and antisense primer, 5'-GTACCAGAGCGTAACCACCACAGG-3'; cyclin D, sense primer, 5'-AGA CCT GCG CGC CCT CGG TG-3', and antisense primer, 5'-GTA GTA GGA CAG GAA GTT GTT C-3'; and GAPDH, sense primer, 5'-CGA GAT CCC TCC AAA ATC AA-3', and antisense primer, 5'-AGG TCC ACC ACT GAC ACG TT-3'. Transcripts were quantified using electrophoresis on $2 \%$ agarose gels. All assays were performed in triplicate.

Western blotting. The lysates from HepG2 cells were separated by sodium dodecyl sulfate-polyacrylamide gel electrophoresis (SDS-PAGE) according to previously described protocols (16). Supernatant protein concentrations were determined using the Bio-Rad DC protein assay reagents (Bio-Rad, Hercules, CA, USA). The proteins were transferred to polyvinylidene difluoride (PVDF) membranes (Amersham Pharmacia Biotech, Buckinghamshire, UK), which were blocked overnight at $4^{\circ} \mathrm{C}$ in Tris-buffered saline containing $0.1 \%$ Tween-20 and 5\% bovine serum albumin (BSA). The membranes were then incubated overnight at $4^{\circ} \mathrm{C}$ with specific antibodies diluted at 1:1,000. Immune complexes were further incubated with their respective peroxidase-conjugated secondary antibodies diluted at 1:1,000 for $1 \mathrm{~h}$. The membranes were analyzed using chemiluminescent reactions (ECL Plus kit; Amersham Pharmacia Biotech), after which protein expressions were visualized and analyzed using ImageJ software (National Institutes of Health, Bethesda, MD, USA).

Determination of standard components by high-performance liquid chromatography (HPLC). The methanol extract of $\mathrm{CO}$ was analyzed using an HPLC system (Agilent 1100 series; 

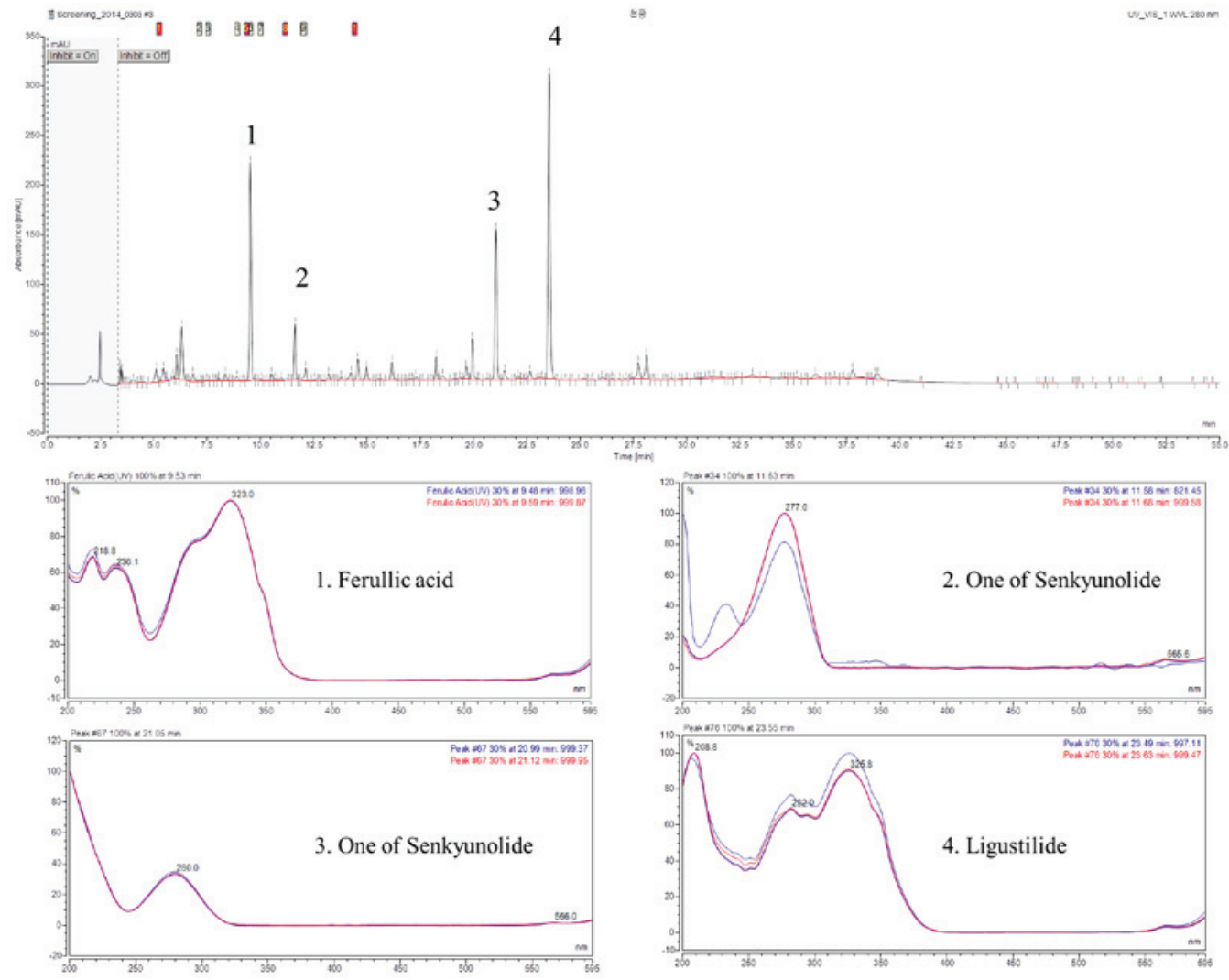

Figure 1. The chromatogram of Cnidium officinale Makino (CO) extract analyzed by high-performance liquid chromatography (HPLC). The composition of $\mathrm{CO}$ extract were analyzed by determining the presence of nine standard compositions including cnidilide, ligustilide, neocnidilide, butylphalide, senkyunolide, tetramethylpyrazine, caffeic acid, ferulic acid, and perlolyrine, by HPLC. Ferulic acid (1), cnidilide (2), senkyunolide (3), and ligustilide (4) were identified from $\mathrm{CO}$ extract.

Agilent Technologies, Santa Clara, CA, USA) equipped with a Phenomenex column $\left(\mathrm{C} 18,4.06 \_250 \mathrm{~mm}\right)$. An isocratic mixture of $\mathrm{CH}_{3} \mathrm{CN}: \mathrm{MeOH}: \mathrm{H}_{2} \mathrm{O}$ (60:30:10) was used as the mobile phase at a flow rate of $1.0 \mathrm{ml} / \mathrm{min}$. Absorbance was measured at $210 \mathrm{~nm}$. Standard stock solutions of cnidilide, ligustilide, neocnidilide, butylphalide, senkyunolide, tetramethylpyrazine, caffeic acid, ferulic acid, and perlolyrine were prepared by dissolving $1 \mathrm{mg} / \mathrm{ml}$ of analytical standard in methanol and stored at $4^{\circ} \mathrm{C}$ prior to use.

Statistical analysis. The results were expressed as mean \pm standard deviation (SD) of three independent experiments. Statistical differences among means were calculated by using ANOVA (one-way) followed by Duncan's multiple range test. The results of cell cycle analysis were tested using Pearson's Chi-square test. Differences with $\mathrm{P}<0.05$ were considered significant. The statistical software package SPSS 10.0 (SPSS Institute, Chicago, IL, USA) was used for these analyses.

\section{Results}

Determination of active components in $\mathrm{CO}$. The composition of $\mathrm{CO}$ extract was analyzed by determining the presence of nine standard compounds, including cnidilide, ligustilide, neocnidilide, butylphalide, senkyunolide, tetramethylpyrazine, caffeic acid, ferulic acid, and perlolyrine by HPLC. As shown in Fig. 1, major four compounds were identified as including ferulic acid, cnidilide, senkyunolide, and ligustilide.
Cell viability. The effect of $\mathrm{CO}$ on the Chang liver cell viability was determined by XTT assay. The results indicated that $\mathrm{CO}$ was not cytotoxic at concentrations between $100-1,000 \mu \mathrm{g} / \mathrm{ml}$ (Fig. 2A). The viability of HepG2 cells treated for $24 \mathrm{~h}$ with increasing concentrations of $\mathrm{CO}$ extract was assessed. As shown in Fig. 2B, HepG2 cell viability significantly decreased after treatment with $\mathrm{CO}$ extract at $100,250,500,750$, and $1,000 \mu \mathrm{g} / \mathrm{ml}$.

Effects of $\mathrm{CO}$ on apoptotic cell morphology. In order to investigate whether $\mathrm{CO}$ has an apoptotic effects, HepG2 cells treated with $\mathrm{CO}$ extract were stained by Hoechst 33258 staining and identified cells undergoing apoptosis by cell imaging reader. As shown in Fig. 3, the marked cells (yellow color) indicate the apoptotic cells. Apoptotic cells in the group treated with $\mathrm{CO}$ extract were increased compared with the untreated group in a dose-dependent manner.

Inhibitory effect of $\mathrm{CO}$ on cell cycle. To further examine the apoptotic characteristics in HepG2 cells treated with $\mathrm{CO}$ extract, the cell cycle phases were analyzed. As shown in Fig. 4, the percentage of S phase cells reduced to 3.5, 4.4, $5.9,7.3$, and $9.9 \%$ at $24 \mathrm{~h}$ following treatment with 100,250 , 500,750 , and $1,000 \mu \mathrm{g} / \mathrm{ml} \mathrm{CO}$ extract, respectively but did not show any significant difference.

Effect of $\mathrm{CO}$ on the expression of cell cycle- and apoptosis-related genes in HepG2 cells. As shown in Fig. 5, 
A

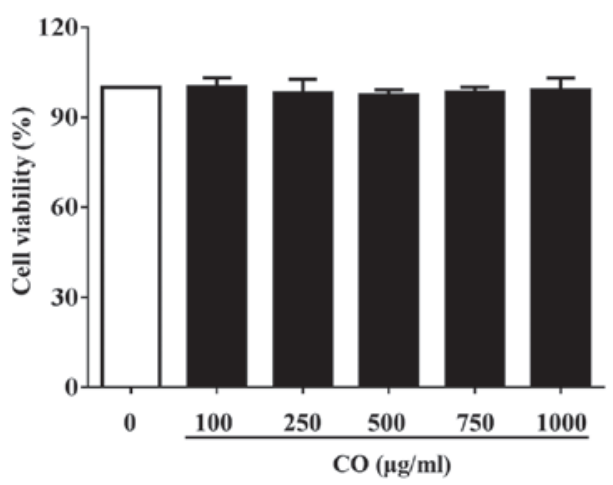

B

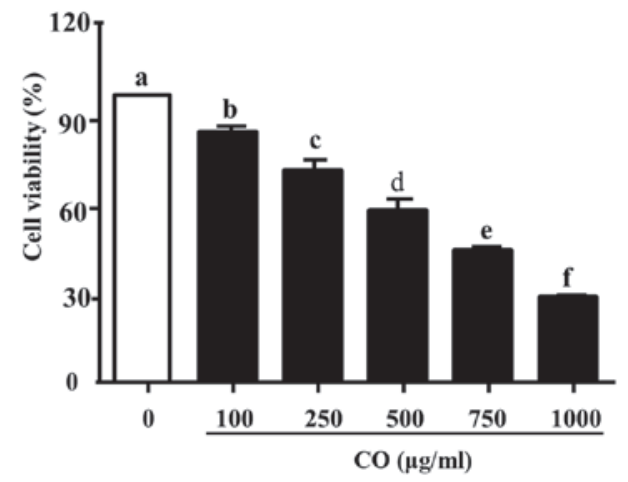

Figure 2. Effects of varying concentrations of Cnidium officinale Makino (CO) extract on the viability of the Chang liver cells and human hepatocellular carcinoma (HepG2) cells. (A) Chang liver and (B) HepG2 cells were treated with 100-1,000 $\mu \mathrm{g} / \mathrm{ml} \mathrm{CO}$ extract for $24 \mathrm{~h}$ and cell viability was assessed using the EZ-Cytox cell viability assay kit. Data are expressed as means \pm standard deviation (SD) of three independent experiments. Untreated Chang liver cells and HepG2 cells were considered $100 \%$ viable. Values with different superscripted letters are significantly different at $\mathrm{P}<0.05$ by Duncan's multiple range test.

A

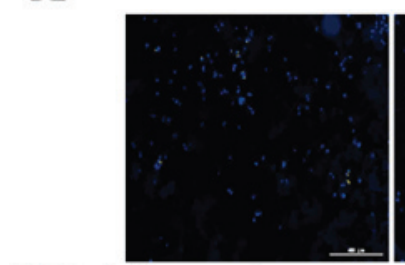

$\mathrm{CO}(\mu \mathrm{g} / \mathrm{ml})$

0

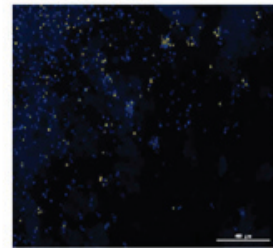

$\mathrm{CO}(\mu \mathrm{g} / \mathrm{ml})$

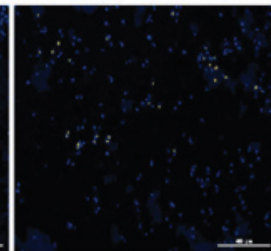

100

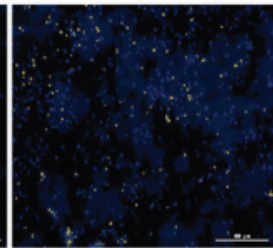

750

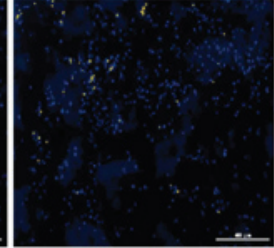

250

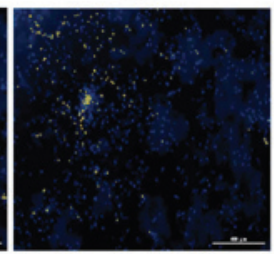

1000
B

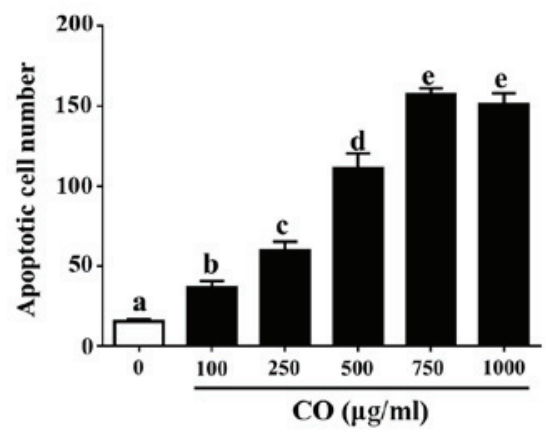

Figure 3. Effects of Cnidium officinale Makino (CO) extract on apoptotic morphology in HepG2 cells. HepG2 cells were seeded and incubated for $12 \mathrm{~h}$. Then, cells were treated with different concentrations of $\mathrm{CO}(0-1,000 \mu \mathrm{g} / \mathrm{ml})$ for $24 \mathrm{~h}$ and stained with Hoechst 33258 staining. (A) The yellow cells mean apoptotic cells. Apoptotic cells automatically showed yellow and were counted by the machine program. (B) Data are mean \pm SD ( $n=3$ ), values with different superscripted letters are significantly different at $\mathrm{P}<0.05$ by Duncan's multiple range test.

A

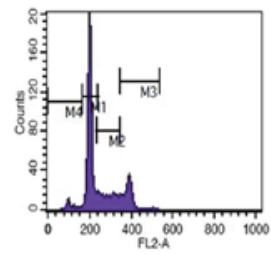

$\mathrm{CO}(\mu \mathrm{g} / \mathrm{ml}) \quad 0$

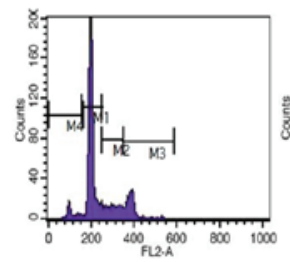

$\mathrm{CO}(\mu \mathrm{g} / \mathrm{ml})$

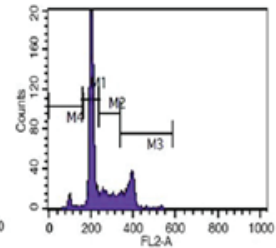

100

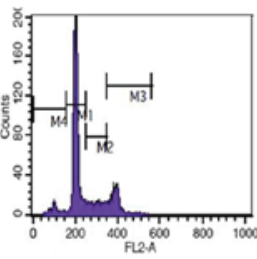

750

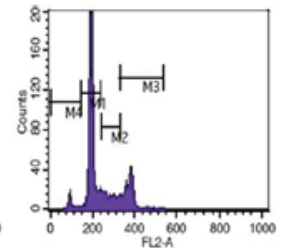

250

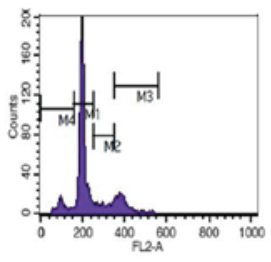

1000
B

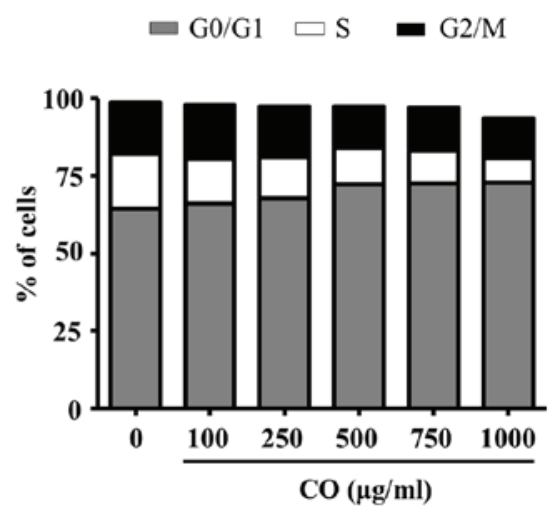

Figure 4. Effects of Cnidium officinale Makino (CO) extract on HepG2 cell cycle progression. The cells were incubated with CO extract (0-1,000 $\mu \mathrm{g} / \mathrm{ml})$ for $24 \mathrm{~h}$. Cell cycles were determined by fluorescence-activated cell sorting (FACS) analysis. Each item was derived from representative experiments, where data was obtained from at least 10,000 events. (A) The cell populations in G0/G1, S, and G2/M phases were determined using the BD CellQuest Pro software. (B) The graph indicates the fluorescence intensity of incorporated propidium iodide (PI, \%) in each phase of cell cycle. 
A

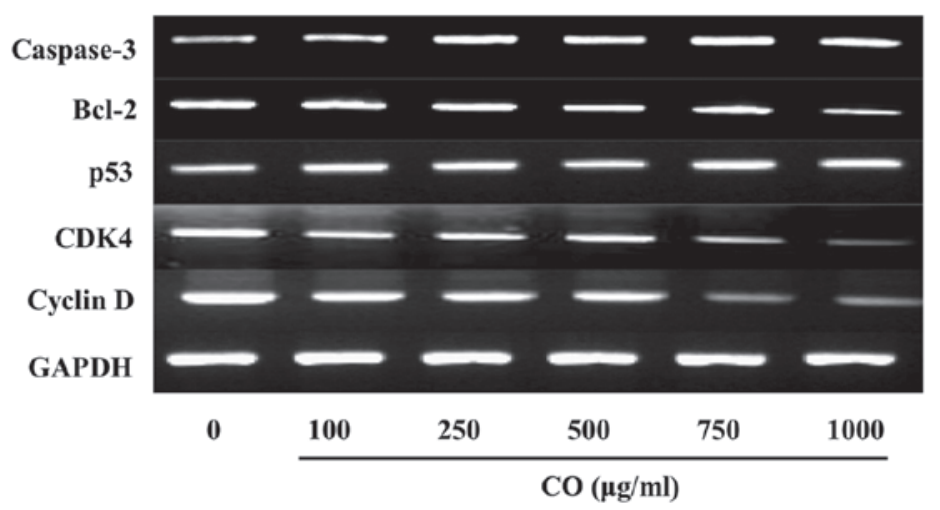

C

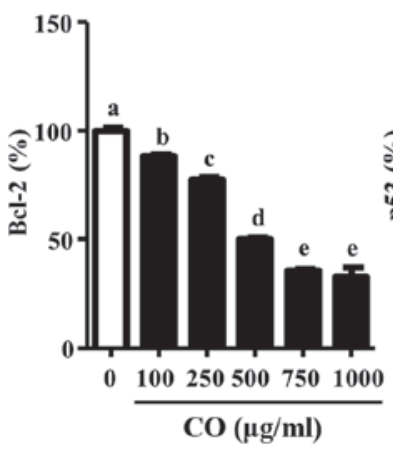

D

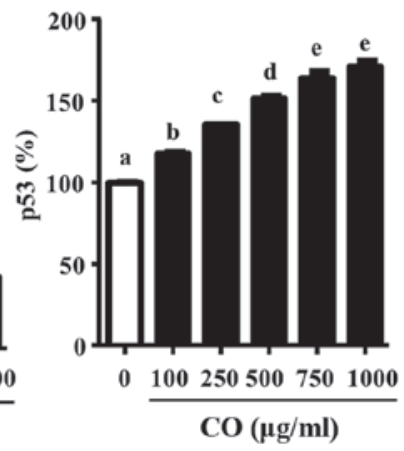

B

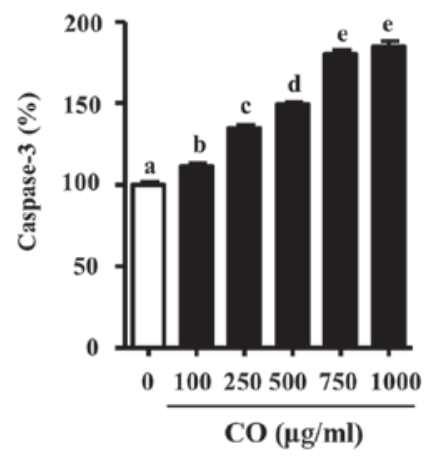

F

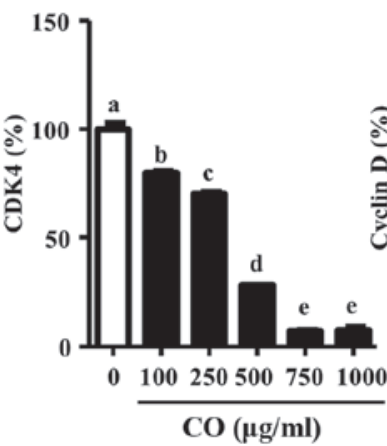

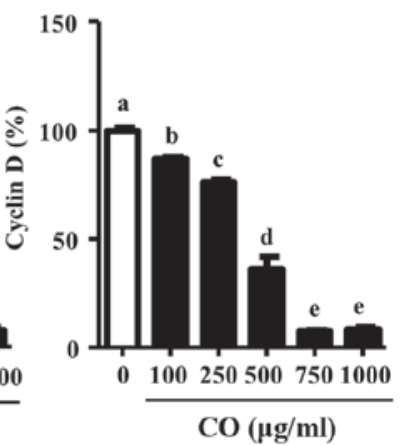

Figure 5. Effects of Cnidium officinale Makino (CO) extract on the expression of capase-3, B-cell lymphoma 2 (Bcl-2), tumor protein 53 (p53), cyclin-dependent kinase 4 (CDK4), and cyclin D mRNA in HepG2 cells. HepG2 cells were incubated with or without CO extract (100-1,000 $\mu$ g/ml) for 24 h. (A) The expression levels of caspase-3, Bcl-2, p53, CDK4, and cyclin D were determined by reverse transcriptase polymerase chain reaction (RT-PCR). The cells were lysed, and mRNA was analyzed by agarose gel electrophoresis. (B-F) Densitometry scanning data of the ratios of caspase-3, Bcl-2, p53, CDK4, and cyclin D. Untreated HepG2 cells were $100 \%$ viable. Data are mean \pm SD $(n=3)$, values with different superscripted letters are significantly different at $P<0.05$ by Duncan's multiple range test.

mRNA levels of caspase-3 increased to $11.4,34.5,49.4$ 80.0 , and $84.7 \%$ and those of $\mathrm{p} 53$ to $17.1,39.4,51.0,63.5$, and $70.7 \%$, respectively, after treatment with 100, 250, 500, 750, and $1,000 \mu \mathrm{g} / \mathrm{ml} \mathrm{CO}$. Conversely, the same concentrations of $\mathrm{CO}$ decreased the levels of Bcl-2 by 9.2, 20.0, 47.6, 62.0, and $64.7 \%$, respectively. In addition, CDK4 expression decreased after treatment with the same concentrations of the $\mathrm{CO}$ extract to $14.1,23.9,66.0,87.1$, and $86.4 \%$, respectively, and those of cyclin D decreased by $13.6,24.2,64.2,92.8$, and $92.0 \%$, respectively.

Effect of $\mathrm{CO}$ on the expression of cell cycle-and apoptosis-related proteins in HepG2 cells. We analyzed the expression of cell cycle- and apoptosis-related proteins to investigate the molecular mechanism by which $\mathrm{CO}$ extract triggered cell cycle regulation and apoptosis in HepG2 cells. The protein levels of caspase-3 and p53 increased after CO treatment in a dose-dependent manner. In contrast, those of Bcl-2 and cell cycle enzymes decreased in a dose-dependent manner after treatment with the same concentrations of $\mathrm{CO}$ extract (Fig. 6).

Effect of $\mathrm{CO}$ on cleaved caspase-3 in HepG2 cells. The expression levels of caspase-3 in HepG2 cells were determined following treatment with $\mathrm{CO}$ extract using western blot analysis. As shown in Fig. 7, the percentage of cleaved caspase-3 increased to $32.4,64.3,93.5,127.0$, and $133.5 \%$ following a 24-h treatment with $\mathrm{CO}$ extract at concentrations of $100,250,500,750$, and $1,000 \mu \mathrm{g} / \mathrm{ml}$, respectively.

\section{Discussion}

Apoptosis is regarded as an important cellular mechanism that occurs in response to abnormalities and cell damage $(6,9)$. Anomalous apoptotic responses are prominent in the development and progression of many types of human cancers $(17,18)$. One of the chemopreventive strategies in the treatment of cancer is the induction of apoptotic cell death (7). Natural compounds are rich sources of anticancer agents that can induce apoptosis and DNA repair in response to mutations (10). Previous studies have shown that essential oils and compounds from medicinal herbs can be used to treat human diseases owing to their potent biological activities against abnormal physiological reactions in the body (19-22). Our research confirmed that the major components of $\mathrm{CO}$, including ferulic acid, cnidilide, senkyunolide, and ligustilide, induced apoptotic cell death in HepG2 cells. It has been established that rhizomes of CO contain 1-2\% of essential oils and active compounds, such as cnidilide, ligustilide, neocnidilide, butylphalide, senkeyunolide, tetramethylpyrazine, caffeic acid, ferulic acid, and perlolyrine (23). In addition, several recent reports have highlighted 
A

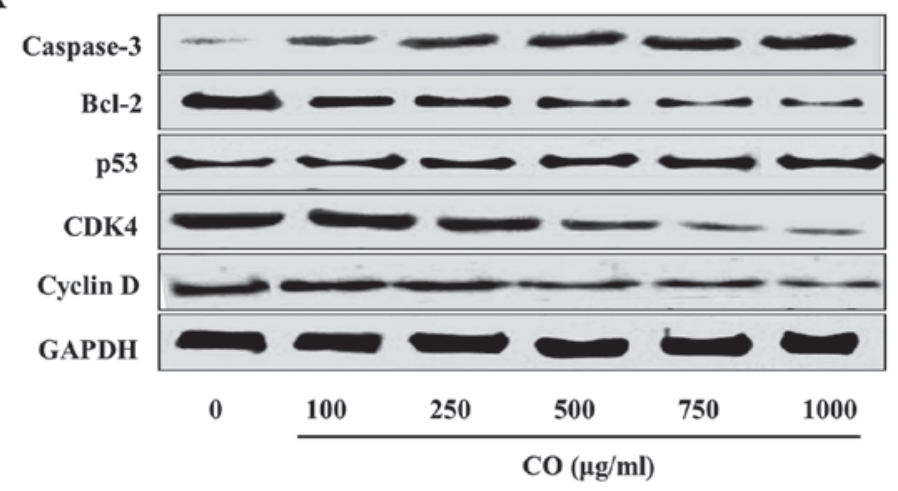

C

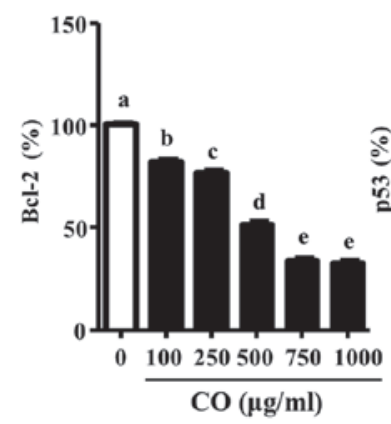

D

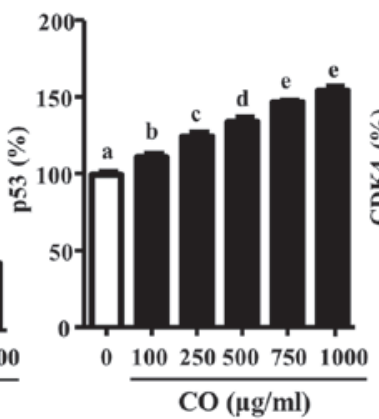

E

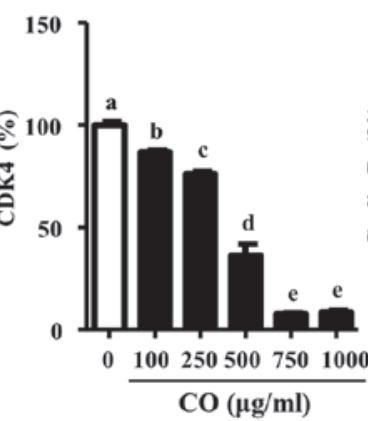

B

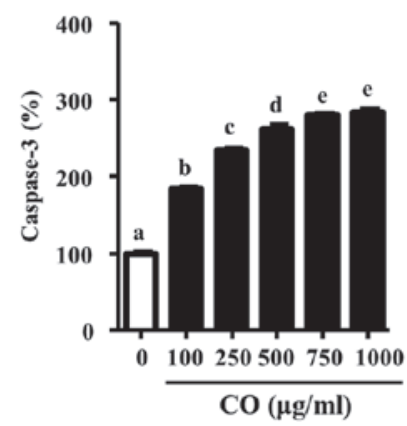

F

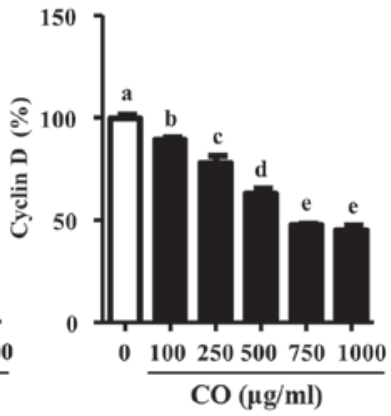

Figure 6. Effects of Cnidium officinale Makino (CO) extract on capase-3, Bcl-2, p53, CDK4, and cyclin D protein expressions in HepG2 cells. HepG2 cells were seeded in 6-well plates and incubated for $24 \mathrm{~h}$. HepG2 cells were incubated in the presence or absence of CO extract $(100-1,000 \mu \mathrm{g} / \mathrm{ml})$ for $24 \mathrm{~h}$. (A) The expression levels of caspase-3, Bcl-2, p53, CDK4, and cyclin D were determined by western blot analysis. (B-F) The graph shows the densitometry scanning analysis of the ratios of caspase-3, Bcl-2, p53, CDK4, and cyclin D. Untreated HepG2 cells were considered to have $100 \%$ viability. Data are mean \pm SD ( $\mathrm{n}=3$ ), values with different superscripted letters are significantly different at $\mathrm{P}<0.05$ by Duncan's multiple range test.

A

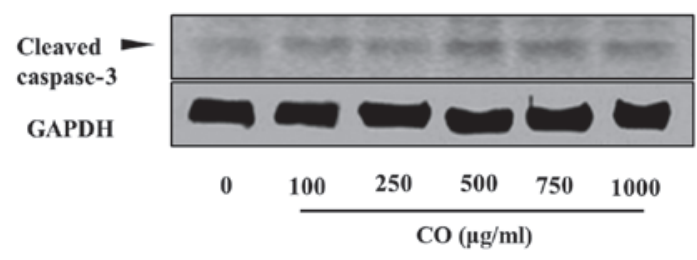

B

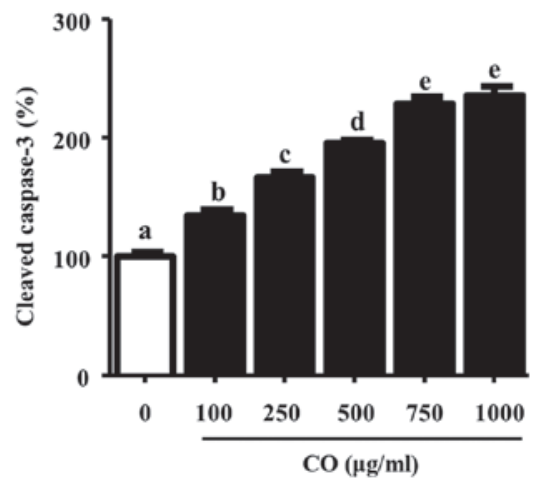

Figure 7. Effects of Cnidium officinale Makino (CO) extract on caspase-3 in HepG2 cells. HepG2 cells were seeded and incubated in the presence or absence of $\mathrm{CO}(100-1,000 \mu \mathrm{g} / \mathrm{ml})$ for $24 \mathrm{~h}$. (A) Apoptosis regulatory proteins, such as caspase-3 and cleaved caspase-3, were assayed by western blot analysis. (B) Densitometric quantification of data, which are expressed as means \pm SD of three independent experiments. The viability of untreated HepG 2 cell was considered $100 \%$. Values with different superscripted letters are significantly different at $\mathrm{P}<0.05$ by Duncan's multiple range test. the anti-inflammatory and anticancer effects of $\mathrm{CO}(14,24)$. Lee demonstrated that ferulic acid, a phenolic compound, induced apoptosis in HepG2 cells through the generation of reactive oxygen species (ROS) (25). Kan et al also confirmed the anticancer effects of senkyunolide A and Z-ligustilide in colon cancer (26).

Cell growth is regulated by CDK and its binding proteins, such as the cyclins. In G1 phase, CDK4 and cyclin D enzymes are known to initiate cell division (27). Interestingly, Musgrove et al claimed that cyclin D is one of the therapeutic target molecules in cancer therapy (28). Cyclin D 1 plays an important role in the progression of G1 to $\mathrm{S}$ phase of the cell cycle in normal cells through the activation of CDK4 (14). In this study, treatment with the methanol extract of $\mathrm{CO}$ significantly reduced $\mathrm{HepG} 2$ cell viability. In addition, the Hoechst 33258 staining demonstrated that apoptosis in HepG2 cell were increased with the increasing $\mathrm{CO}$ extract concentrations. We confirmed G0/G1 arrest and reduction of cell population in $\mathrm{S}$ phase via the suppression of CDK4 and cyclin D expression in the CO-treated HepG2 cells.

The $\mathrm{p} 53$ tumor suppressor gene is a pivotal molecule mediating cell cycle arrest and apoptosis (29). Furthermore, this regulation subsequently inhibits the activity of cell cycle-regulating enzymes and the expression of the anti-apoptotic protein Bcl-2 (8). Reduction in the expression of $\mathrm{Bcl}-2$ signaling molecules has been reported as anticancer mechanisms in diverse types of cancers (4). RT-PCR and western blot data showed that $\mathrm{CO}$ extract induced the activation of the tumor 
suppressor protein p53 and decreased levels of the anti-apoptotic protein Bcl-2 in a dose-dependent manner. Moreover, our result confirmed a dramatic increase of caspases- 3 activity in the $\mathrm{CO}$ methanol extract-treated cells compared to that in the untreated cells, which was confirmed by associated increase in the expression of cleaved caspase-3. Caspase- 3 is synthesized as an inactive proenzyme that is activated by cleavage in apoptosis (30). It is known that apoptosis is associated with p53-dependent signaling pathways that regulate caspase-3 expression (31). Our data also revealed that CO extract activated the p53 gene, causing a cascade of events leading to the activation of caspase- 3 and finally cell death.

Taken together, we suggest that $\mathrm{CO}$ extract may effectively induce apoptosis of HepG2 cells through activation of p53 and reduction of $\mathrm{Bcl}-2$. Therefore, $\mathrm{CO}$ is a promising and potential source of polyphenol compounds that may prove effective as chemoprevention agents for hepatocellular carcinoma.

\section{References}

1. Ferlay J, Shin HR, Bray F, Forman D, Mathers C and Parkin DM: Estimates of worldwide burden of cancer in 2008: GLOBOCAN 2008. Int J Cancer 127: 2893-2917, 2010.

2. Hoshida Y, Fuchs BC and Tanabe KK: Prevention of hepatocellular carcinoma: Potential targets, experimental models and clinical challenges. Curr Cancer Drug Targets 12: 1129-1159, 2012.

3. Fulda S: Tumor resistance to apoptosis. Int J Cancer 124: 511-515, 2009.

4. Henson PM and Hume DA: Apoptotic cell removal in development and tissue homeostasis. Trends Immunol 27: 244-250, 2006.

5. Peter ME: Programmed cell death: Apoptosis meets necrosis. Nature 471: 310-312, 2011.

6. Strano S, Dell'Orso S, Di Agostino S, Fontemaggi G, Sacchi A and Blandino G: Mutant p53: An oncogenic transcription factor Oncogene 26: 2212-2219, 2007.

7. Ong TP, Cardozo MT, de Conti A and Moreno FS: Chemoprevention of hepatocarcinogenesis with dietary isoprenic derivatives: Cellular and molecular aspects. Curr Cancer Drug Targets 12: 1173-1190, 2012.

8. Santoro R, Strano S and Blandino G: Transcriptional regulation by mutant p53 and oncogenesis. Subcell Biochem 85: 91-103, 2014.

9. Shen Y and White E: p53-dependent apoptosis pathways. Adv Cancer Res 82: 55-84, 2001.

10. Rahman HS, Rasedee A, Yeap SK, Othman HH, Chartrand MS, Namvar F, Abdul AB and How CW: Biomedical properties of a natural dietary plant metabolite, zerumbone in cancer therapy and chemoprevention trials. Biomed Res Int 2014: 920742, 2014.

11. Ramalingam $M$ and Yong-Ki P: Free radical scavenging activities of Cnidium officinale Makino and Ligusticum chuanxiong Hort. methanolic extracts. Pharmacogn Mag 6: 323-330, 2010.

12. Jeon S, Bose S, Hur J, Jun K, Kim YK, Cho KS and Koo BS A modified formulation of Chinese traditional medicine improves memory impairment and reduces $A \beta$ level in the Tg-APPswe/PS1dE9 mouse model of Alzheimer's disease. J Ethnopharmacol 137: 783-789, 2011.

13. Lee KE, Shin JA, Hong IS, Cho NP and Cho SD: Effect of methanol extracts of Cnidium officinale Makino and Capsella bursa-pastoris on the apoptosis of HSC-2 human oral cancer cells. Exp Ther Med 5: 789-792, 2013.
14. de la Cruz J, Kim DH and Hwang SG: Anti cancer effects of Cnidium officinale Makino extract mediated through apoptosis and cell cycle arrest in the HT-29 human colorectal cancer cell line. Asian Pac J Cancer Prev 15: 5117-5121, 2014.

15. Jung HW, Seo UK, Kim JH,Leem KH and Park YK: Flower extract of Panax notoginseng attenuates lipopolysaccharide-induced inflammatory response via blocking of NF-kappaB signaling pathway in murine macrophages. J Ethnopharmacol 122: 313-319, 2009.

16. Lee KP, Sudjarwo GW, Kim JS, Dirgantara S, Maeng WJ and Hong H: The anti-inflammatory effect of Indonesian Areca catechu leaf extract in vitro and in vivo. Nutr Res Pract 8: 267-271, 2014.

17. Labbé DP, Zadra G, Ebot EM, Mucci LA, Kantoff PW, Loda M and Brown M: Role of diet in prostate cancer: The epigenetic link. Oncogene 34: 4683-4691, 2015.

18. Karsli-Ceppioglu S, Dagdemir A, Judes G, Ngollo M, Penault-Llorca F, Pajon A, Bignon YJ and Bernard-Gallon D: Epigenetic mechanisms of breast cancer: An update of the current knowledge. Epigenomics 6: 651-664, 2014.

19. Hennebelle T, Sahpaz S, Dermont C, Joseph H and Bailleul F: The essential oil of Lippia alba: Analysis of samples from French overseas departments and review of previous works. Chem Biodivers 3: 1116-1125, 2006.

20. Chaieb K, Hajlaoui H, Zmantar T, Kahla-Nakbi AB, Rouabhia M, Mahdouani K and Bakhrouf A: The chemical composition and biological activity of clove essential oil, Eugenia caryophyllata (Syzygium aromaticum L. Myrtaceae): A short review. Phytother Res 21: 501-506, 2007.

21. Mercier B, Prost J and Prost M: The essential oil of turpentine and its major volatile fraction (alpha- and beta-pinenes): A review. Int J Occup Med Environ Health 22: 331-342, 2009.

22. Langeveld WT, Veldhuizen EJ and Burt SA: Synergy between essential oil components and antibiotics: A review. Crit Rev Microbiol 40: 76-94, 2014.

23. Jeong JB, Ju SY, Park JH, Lee JR, Yun KW, Kwon ST, Lim JH, Chung GY and Jeong HJ: Antioxidant activity in essential oils of Cnidium officinale makino and Ligusticum chuanxiong Hort and their inhibitory effects on DNA damage and apoptosis induced by ultraviolet B in mammalian cell. Cancer Epidemiol 33: 41-46, 2009.

24. Bae KE, Choi YW, Kim ST and Kim YK: Components of rhizome extract of Cnidium officinale Makino and their in vitro biological effects. Molecules 16: 8833-8847, 2011.

25. Lee YS: Role of NADPH oxidase-mediated generation of reactive oxygen species in the mechanism of apoptosis induced by phenolic acids in HepG2 human hepatoma cells. Arch Pharm Res 28: 1183-1189, 2005.

26. Kan WL, Cho CH, Rudd JA and Lin G: Study of the anti-proliferative effects and synergy of phthalides from Angelica sinensis on colon cancer cells. J Ethnopharmacol 120: 36-43, 2008.

27. Bertoli C, Skotheim JM and de Bruin RA: Control of cell cycle transcription during G1 and S phases. Nat Rev Mol Cell Biol 14: 518-528, 2013.

28. Musgrove EA, Caldon CE, Barraclough J, Stone A and Sutherland RL: Cyclin D as a therapeutic target in cancer. Nat Rev Cancer 11: 558-572, 2011.

29. Schuler M, Bossy-Wetzel E, Goldstein JC, Fitzgerald P and Green DR: p53 induces apoptosis by caspase activation through mitochondrial cytochrome c release. J Biol Chem 275: 7337-7342, 2000.

30. Sabine VS, Faratian D, Kirkegaard-Clausen T and Bartlett JM: Validation of activated caspase- 3 antibody staining as a marker of apoptosis in breast cancer. Histopathology 60: 369-371,2012.

31. Cregan SP, MacLaurin JG, Craig CG, Robertson GS Nicholson DW, Park DS and Slack RS: Bax-dependent caspase-3 activation is a key determinant in p53-induced apoptosis in neurons. J Neurosci 19: 7860-7869, 1999. 